\title{
Motherhood wage penalties and labour market segmentation: Evidence from Argentina
}

\author{
Maria del Pilar Casal and Bradford L. Barham
}

ABSTRACT

This article explores the connection between labour market segregation and motherhood wage penalties in Argentina across the formal and informal sectors. It uses ordinary least square and quantile regression estimation strategies and deploys Blinder-Oaxaca and Ñopo decompositions to identify sources of wage differences. The finding is that there is strong evidence of labour market segmentation and that motherhood wage penalties differ substantively across the sectors and between different wage quantiles. In particular, formal-sector working mothers do not experience wage penalties, while informal ones do. The motherhood wage penalty increases with the number of children, especially younger children, and is greatest at the bottom and next greatest at the top of the conditional wage distribution. Economics of the University of Wisconsin-Madison. casal@wisc.edu

Bradford L. Barham is a Professor at the Department of Agricultural and Applied Economics of the University of Wisconsin-Madison. barham@aae.wisc.edu 


\section{I}

\section{Introduction}

Rapid growth in women's labour market participation is one of the world's major transformations of the past half century (Goldin, 2006). Economic and social relationships have changed dramatically in many spheres of life, offering women much more power and control over their lives, but certainly not without important limitations and differences depending on the type of jobs they secure and the family they come from and help to create (Babcock and Laschever, 2003). Women still face major challenges in securing gender equality, and motherhood appears to be a "natural" explanation for why working females could be in a disadvantaged position (Budig and England, 2001). Thus, the extent to which institutional factors such as laws, rules and norms that protect mothers can shape wage outcomes and labour market experiences for women is a question of critical importance for policy everywhere.

This article is the first to examine motherhood wage penalties in a Latin American context where labour market segmentation could lead to distinct outcomes across sectors as a result of differing institutional rules. Specifically, it investigates whether segmentation of the labour market into formal and informal sectors leads to dissimilar experiences for Argentine mothers and nonmothers by analysing their wage outcomes. During the 1990s, liberalization and structural adjustment policies affected the dynamics of Argentine labour markets in major ways, gave rise to increasing poverty and inequality, and led to insecure and substandard employment outcomes (De Pablo, 2005). A combination of increasing unregistered employment and unemployment — driven in part by a significant increase in women's labour force participation - and a decline in the purchasing power of wages characterized this era, when formal employment shrank and unregistered, or informal, employment increased notably in scale (Faur, 2008a). In view of these changes, it is useful to investigate whether the division of the labour market into formal and informal sectors gives rise to distinctive motherhood penalties. This is done by examining formal- and informal-sector wages for mothers and non-mothers in Argentina between 1995 and 2003, a period that spans the main liberalization policies set in motion in the early 1990s (Pastor and Wise, 1999).

The main empirical questions addressed are: (i) Do women working in the informal sector earn significantly lower wages than formal workers, as predicted by traditional labour market segmentation theory? (ii) Is there a motherhood wage penalty in either or both sectors? (iii) If so, is the penalty distinct for formal and informal workers? Our hypothesis is that the answers to all the above questions are affirmative because of the ways in which segmented labour markets differentially protect mothers working in the formal and informal sectors. Specifically, women are expected to fare better in the formal sector, where legal and customary protections may allow them to earn higher wages and sustain them during motherhood.

To investigate these issues, Mincerian wage estimations are undertaken with a series of different specifications. In addition to ordinary least square (OLS) wage estimations, quantile methods are used to explore the potential for distinct motherhood penalties in different segments of the wage distribution, as these make it possible to focus specifically on identifying "glass ceilings" at the higher end and "sticky floors" at the lower end of the spectrum. ${ }^{1}$ A Blinder-Oaxaca (BO) decomposition is employed to examine wage differentials in two parts, one that identifies the human capital and other measurable factors that can drive wage differences and a second that recovers an unexplained component, which is associated with discrimination. Finally, во decomposition is complemented by a non-parametric alternative decomposition developed by Nopo (2008). This allows for a better explanation of motherhood wage differentials, since it also shows how much of the gap calculated is accounted for by the outcomes of mothers and non-mothers outside the common support.

The empirical results are consistent with traditional labour market segmentation theory and the hypothesis that women working in the informal sector earn significantly less than their formal worker counterparts. Moreover, women in the informal sector experience a statistically

\footnotetext{
1 The sticky floor hypothesis concerns potential barriers to the advancement of women such as family commitments, attitudes, stereotyping and organizational structures in groups with lower education and wages. The glass ceiling hypothesis concerns the discrimination that women and minorities in more educated groups often face in trying to move up the hierarchy of an organization, especially when they have more children, by comparison with men and with childless women.
} 
significant motherhood wage penalty, while in the formal sector most of the estimated coefficients associated with motherhood and children are not significant. The quantile regression $(\mathrm{QR})$ results vary substantively across the conditional wage distribution; the poorest $10 \%$ of the informal women sample are the ones who suffer the largest motherhood wage penalties. These results are largely consistent across this whole era of liberalization reforms, though some notable differences emerge in comparisons of wage penalties before and after the collapse of the Argentine peso in the late 1990s.

\section{II}

\section{Literature review}

\section{Labour market segmentation}

Labour market segmentation theory challenges neoclassical economic theory and its reflection in human capital theory by arguing that workers and jobs are not matched smoothly by a universal market mechanism (Rosenzweig, 1988). Instead, jobs and labour differ across markets. The traditional view highlights a dual split between primary (or independent) and secondary (or subordinate) segments and contends that the boundaries between the segments substantively limit occupational mobility (Bauder, 2001). One implication is that formalsector labour markets exhibit some form of wage rigidity in which wages remain above the market clearing level. In this conventional view from the literature, unregulated wage employment and self-employment are treated as a free-entry residual sector that is informal in character. Given mobility and wage rigidities in the formal sector, labour markets become inefficient, resulting in the need for structural reforms. However, recent work has questioned the traditional view and argued that duality can also be present in the informal sector itself (Pagés and Stampini, 2007; Fields, 2008).

The empirical evidence on labour market segmentation is diverse, and not all researchers find evidence of higher wages for formal-sector workers. Given that worker mobility is usually correlated with wage differences between sectors, the size of the wage gap itself is also an indicator of labour market segmentation. Maloney (1999), using data from Mexico, cannot prove or disprove segmentation based on earnings differentials, because movement into self-employment from every other
Overall, the formal and informal sectors have distinct wage structures that are consistent with a different set of institutions and rules shaping the labour market experiences of women and mothers.

The remainder of the article is organized as follows. Section II discusses the motherhood wage penalty and labour market segmentation literatures. Section III describes the empirical strategy and methodology. Section IV discusses the main features of the data and Section V presents the results. Section VI offers conclusions. sector is associated with a substantial and significant rise in per-hour after-tax remuneration. Gong and van Soest (2002) show that in urban Mexico wage differentials increase with educational level, especially in the formal sector. For instance, other things being equal, a highly educated man can earn approximately $150 \%$ more than a man with the lowest education level in the formal sector, while in the informal sector a man with a similar level of education earns only $44 \%$ more. The pattern is similar for women, although standard errors are much larger given the small number of observed wages. Packard (2007) offers a cross-sectional examination of wage differentials in Chile, and the results of the correction for sample selection bias highlight the finding that selfemployed workers earn up to twice as much as employees on contracts (formal employees). However, interpreting these results requires caution, since he finds a positive sample selection bias towards self-employment and employment without a contract.

Botelho and Ponczek (2011) measure the degree of segmentation in the Brazilian labour market using a genuine panel of individuals. They find the average wage differential between formal and informal workers to be $7.8 \%$, suggesting a small degree of segmentation in the Brazilian labour market. They argue that the segmentation phenomenon is closely related to Brazil's labour laws, which leave little room for direct negotiations between firms and employees. Pagés and Stampini (2007) study labour market segmentation using panel data from three Eastern and Central European and three Latin American countries. They find evidence of a wage premium in the formal sector relative to the informal one only in 
Latin America, with no statistical difference across skill levels and no significant wage premium in Eastern and Central European countries. Thus, estimates of the wage premium in Latin America range from 6\% to $12 \%$ for unskilled workers and from $9 \%$ to $20 \%$ for the skilled. Finally, focusing on the case of Argentina, Pratap and Quintin (2006) test the hypothesis that workers earn higher wages in the formal than in the informal sector. While the parametric models suggest there is a formal premium, and it remains after controlling for individual and firm characteristics, the semi-parametric tests used in this article indicate either a negative or a small and insignificant formal premium.

\section{The motherhood wage penalty}

The issue of gender wage gaps has constituted a muchstudied area of research, but far more so in developed countries than in developing ones. Advances in women's educational attainments and increased opportunities for women in the labour market have narrowed the wage gap between men and women and improved women's representation in high-status occupations (Ridgeway and Corell, 2004). Some researchers have argued that the wage gap between men and single women is not significant; nevertheless, the differences in earnings between men and married women remain high (Gangl and Ziefle, 2009). Given the traditional role of women as caregivers, in addition to the traditional wage gap, mothers seem to be the ones who experience most disadvantages, and this "motherhood penalty" has been identified in wage differentials between mothers and non-mothers that control for other human capital factors typically explaining wage differentials.

The great bulk of research on the motherhood penalty focuses on the United States (Waldfogel, 1997 and 1998; Kennelly, 1999; Budig and England, 2001; Anderson, Binder and Krause, 2002 and 2003; Correll, Benard and Paik, 2007), although evidence of a motherhood penalty is also found in the United Kingdom, Germany and Scandinavian countries (Budig and England, 2001; Beblo, Bender and Wolf, 2009). Gangl and Ziefle (2009) have developed an original approach to the motherhood wage penalty that involves cross-country analysis using data from the United States, Germany and Britain. Finally, Piras and Ripani (2005) explore the effects of motherhood on labour force participation and wages in Brazil, Peru, the Plurinational State of Bolivia and Uruguay. Although this was the first paper to focus on the motherhood wage penalty in Latin America, it does not distinguish between potential outcomes in formal and informal markets, where distinct institutional norms hold.

As summarized in Budig and England (2001) and Correll, Benard and Paik (2007), there are several possible explanations for the motherhood penalty. On the one hand, worker explanations are based on differences in endowments, behaviours and characteristics between mothers and non-mothers. First, women who decide to have children interrupt their work experience because they have to spend time at home taking care of their children. Second, motherhood and household duties may leave women exhausted or distracted while working, decreasing their productivity and work effort. Third, women might forego higher-paying employment in favour of family-friendly jobs that allow them to work fewer hours and spend more time at home. On the other hand, discrimination explanations are based on the notion that even though mothers may be equally productive, employers may (for strategic reasons) pay them less than non-mothers and men of similar productivity in the labour market.

Empirical studies offer evidence for both the worker and discrimination explanations. Using longitudinal surveys from the United States, Waldfogel (1997) concludes that an unexplained motherhood wage penalty persists after controlling for human capital, unobserved heterogeneity and part-time employment, with a $4 \%$ penalty for one child and a $12 \%$ penalty for two or more children. Budig and England (2001) use the same longitudinal surveys as Waldfogel. Studying a different time period, they find a $7 \%$ wage penalty per child. Approximately one third of the loss of earnings is explained by job experience, while the remaining two thirds are likely to arise from productivity or employer discrimination issues, or a combination of the two. Anderson, Binder and Krause (2002) find that lower-skilled workers do not suffer a motherhood penalty, while university-educated mothers of two or more children experience a $15 \%$ wage penalty. Gangl and Ziefle (2009) establish that the motherhood penalty ranges from $9 \%$ to $18 \%$ per child across Germany, the United Kingdom and the United States, with Germany exhibiting the highest cost for maternity compared to American and British mothers. Piras and Ripani (2005) show that, without controlling for segmentation, there is a motherhood wage penalty in Peru for mothers of children aged under 7. In the cases of Brazil and the Plurinational State of Bolivia, they find evidence of wage premiums for mothers, and there are no significant results for Ecuador. Finally, 
contrary to the previous finding, Amuedo-Dorantes and Kimmel (2005) examine 19 rounds of the 1979 National Longitudinal Surveys (NLS) and find that university-educated mothers in the United States, far from experiencing a motherhood wage penalty, earn a premium when compared to university-educated childless women, and that fertility delay boosts their pay even further.
The literature reviewed above differs from our article insofar as the evidence for motherhood wage premiums could be explained by labour market segmentation if formal-sector rules protect the rights of mothers and informal-sector rules do not, but that kind of explicit consideration of distinct rules is not part of any of the aforementioned articles, whereas it is the primary focus of this article.

\section{III}

\section{The empirical strategy: methodology}

The basic earnings equation used here and in most wage studies derives from Mincer (1974) and is presented in equation (1) below. In studying labour markets, economists usually define "discrimination" as the presence of different wage rates for workers with the same productivity or ability but with different personal characteristics (such as age, race, sex, nationality, etc.). To determine if there is a wage penalty for having additional children in the two sectors, we include a dummy variable for motherhood in equation (1).

Using the traditional augmented Mincerian earnings equation, the first approximation is the following semilogarithmic linear and additive model:

$$
\ln w_{i j}=\alpha_{i j}+\beta_{1 j} M_{i j}+\beta_{2 j} H_{i j}+\beta_{3 j} F_{i j}+\beta_{4 j} J_{i j}+\mu_{i j}
$$

where $i$ indexes individual women, $j$ indicates two types of employment (formal " $F$ " and informal " $I$ ") and $\mu$ is an error term. Specifically:

- The dependent variable $\ln w_{i}$ is the natural logarithm of the real hourly wage of woman $i$;

- $\quad M$ is a set of dummy variables taking a value of 1 if woman $i$ is the mother of one child, two children or three or more children aged under 15 , and a value of 0 otherwise;

- $H$ is a vector of human capital variables (age, the square of age, education, occupation);

- $F$ is a vector of family categorical variables (civil status, head of household); and

- $J$ is a vector of job characteristic variables (length of time in the same job, full versus part-time worker, public versus private sector, firm size, and economic sectors: services, manufacturing and commerce).
In investigating whether women working in the informal sector earn significantly less than formal workers, the aim is to test the following null hypothesis:

$$
H_{0}: \ln \hat{w}_{I}-\ln \hat{w}_{F}<0
$$

as compared to the alternative hypothesis:

$$
H_{A}: \ln \hat{w}_{I}-\ln \hat{w}_{F} \geq 0
$$

The idea is that, as predicted by traditional labour market segmentation theory, hourly earnings should be significantly higher for those employed in the formal sector. Wage premiums for women employed in the formal sector would support the possibility of segmented labour markets in Argentina.

Moreover, the estimated coefficient of the motherhood dummy variable in equation (1) is expected to be negative in the informal sector and (if specified by the number of children) to increase with the number of children. Faur (2008b) highlights the gender-specific regulations applying to maternity in Argentina. While men are entitled to "family allowances", and the provision of social insurance and pensions for the household is organized around them, women have maternity rights, with mothers being entitled to 90 days' paid maternity leave before or after childbirth, or both. However, enforcement of the law is effective only for those employed in the formal sector (Faur, 2008b, p. 52), and this difference could mean a smaller wage penalty in the formal sector. Indeed, it is possible, one the one hand, that there may be no significant wage differential between mothers and non-mothers in the formal sector, for the following three reasons: (i) pregnant women employed in the formal 
sector are protected from dismissal; (ii) women from wealthier households may not need to be absent from the labour market during pregnancy or may be able to work part-time once they have children because of their ability to afford private childcare or hire domestic help; ${ }^{2}$ and (iii) with ongoing help with domestic duties and childcare, women in the formal segment might be less tired at home and more productive at work.

On the other hand, it seems likely that there is a motherhood wage penalty in the informal segment, given that none of the considerations enumerated above is likely to apply to informal workers who are mothers. Likewise, compared to non-mothers, those in the informal segment who have children might be exposed to discrimination by employers since these may perceive or argue that mothers cost more money and are unlikely to be able to work full-time. Also, the difference in characteristics between mothers and non-mothers could be more evident in the informal sector than in the formal sector because women employed in the informal sector are more likely to be less educated and have more children. Faur (2008b) finds that married women in Argentina are the ones who allocate the greatest proportion of their day to childcare, but this occurs especially in poor households, where many young children do not attend early education programmes, while mothers who work largely do so in the informal sector. Thus, different institutional and social barriers might prevent the poorest women (especially mothers) from accessing employment in the high-wage segment and accentuate the class, gender and motherhood discrimination they face as a result.

In the motherhood penalty literature, most estimation efforts have attempted to address the wage effect of maternity and control for the potential endogeneity of the motherhood variable. The ideal situation would be to use longitudinal data and fixed-effect panel regression methods to control for self-selection, cohort effects or other types of unobserved heterogeneity besides labour participation choices (Gangl and Ziefle, 2009). Unlike those used in some recent work on motherhood wage penalties from the United States and Europe (Walfogel, 1997; Budig and England, 2001; Anderson, Binder and Krause, 2002 and 2003; Gangl and Ziefle, 2009), the

\footnotetext{
2 Faur (2008b) indicates that although the situation with early education facilities in the City of Buenos Aires is quite good in comparison with that in other jurisdictions in Argentina, the childcare coverage available, especially in the education sector, is far from universal. There has been an increase in the demand for places at childcare centres during recent years, and most of this has been met by the private sector. There is growing unmet demand for places at State-run day-care centres and kindergartens from those unable to pay for the care of their children.
}

Argentine household employment data do not have the necessary longitudinal structure. Instead, the sampling strategy is based on rolling cross-sections with regular replacement of respondents.

Our initial approach is thus to estimate the Mincerian wage equation (1) using the classical ordinary least square (OLS) estimation or conditional mean regression. To complement the oLs equation we use the quantile regression (QR) method. ${ }^{3}$ Many useful features of QR models justify this utilization (Buchinsky, 1998; Falaris, 2008; Yasmin, 2009; Olbrecht, 2009). First, QR allows the $\beta$ parameters to vary at different points of the conditional distribution of the dependent variable, and makes it possible to investigate whether workers' productive characteristics have effects that change across the conditional distribution. Second, QR is less sensitive than oLs to outliers in the dependent variable since it minimizes the weighted sum of absolute deviations. Moreover, when the error terms are non-normal, QR also gives a more efficient estimator than least squares. Lastly, QR has a linear programming representation that makes estimation easy.

In classical linear regressions, the sample mean is the solution to the problem of minimizing the sum of squared residuals, while the median is the solution to the problem of minimizing the sum of absolute residuals. In the case of the other quantiles, given that the symmetry of the absolute value yields the median, minimizing the sum of asymmetrically weighted absolute residuals would yield the quantiles:

$$
\min _{\xi \in \mathfrak{R}} \sum_{i=1}^{n} \rho_{\tau}\left(y_{i}-\xi\right)
$$

where the function $\rho_{\tau}($.$) is the absolute value function$ that yields the $\tau$ th sample quantile as its solution.

In the case of the least square regression, given the random sample $\left\{y_{1}, y_{2}, \ldots y_{n}\right\}$ and the following equation:

$$
\min _{\mu \in \mathfrak{R}} \sum_{i=1}^{n}\left(y_{i}-\mu\right)^{2}
$$

if we solve equation (4) then we obtain the sample mean $E(Y)$, which is an estimate of the unconditional population mean. Let us replace the scalar $\mu$ by a parametric function $\mu(x, \beta)$ :

$$
\min _{\beta \in \mathfrak{R}^{p}} \sum_{i=1}^{n}\left(y_{i}-\mu\left(x_{i}-\beta\right)\right)^{2}
$$

\footnotetext{
3 In explaining quantile regression we mostly follow Koenker and Hallock (2001) and Wooldridge (2000).
} 
From equation (5), we get an estimation of the conditional expectation function $E(h x)$. In quantile regressions, we continue in the same way. We replace the scalar $\xi$ in equation (3) by the parametric function $\xi\left(x_{i}, \beta\right)$ and set $\tau$ to $1 / 2$. Finally, to get the other conditional quantile functions, we replace the absolute value by $\rho_{\tau}\left({ }^{(}\right)$:

$$
\min _{\beta \in \mathfrak{R}^{p}} \sum_{i=1}^{n} \rho_{\tau}\left(y_{i}-\xi\left(x_{i}-\beta\right)\right)
$$

The resultant minimization problem, when $\xi\left(x_{i}, \beta\right)$ is formulated as a linear function of parameters, can be solved by linear programming methods.

\section{The Blinder-Oaxaca wage gap decomposition}

Since we are particularly interested in comparing earnings between groups (specifically, formal versus informal and mothers versus non-mothers), we also employ the classical decomposition technique for wage differentials proposed by Blinder (1973) and Oaxaca (1973). The Blinder-Oaxaca (во) decomposition divides the wage differential between two groups into a portion that is "explained" by groups' dissimilarities in productivity characteristics and an "unexplained" residual portion, which is typically used as a measure of discrimination (Jann, 2008).

Suppose we are interested in comparing two demographic groups, $A$ and $B$. We can estimate the following equations for each group:

$$
\begin{gathered}
Y_{i}^{A}=\beta_{i}^{A}+\sum_{i=1}^{n} \beta_{j}^{A} X_{j i}^{A}+u_{i}^{A} \\
Y_{i}^{B}=\beta_{i}^{B}+\sum_{i=1}^{n} \beta_{j}^{B} X_{j i}^{B}+u_{i}^{B}
\end{gathered}
$$

Given the linear equations (7) and (8), the mean outcome difference can be defined as the difference in the linear predictions at the group-specific means of the regressors. Specifically, the raw differential $(R)$ is given by:

$$
\begin{gathered}
R=E\left(Y^{A}\right)-E\left(Y^{B}\right)=\beta_{0}^{A}-\beta_{0}^{B}+\sum_{j} \beta_{j}^{A}\left(\bar{X}_{j}^{A}-\bar{X}_{j}^{B}\right)+ \\
\sum_{j} \bar{X}_{j}^{B}\left(\beta_{j}^{A}-\beta_{j}^{B}\right)=U+E+C
\end{gathered}
$$

where $U=\beta_{0}^{A}-\beta_{0}^{B} ; E=\sum_{j} \beta_{j}^{A}\left(\bar{X}_{j}^{A}-\bar{X}_{j}^{B}\right)$; $C=\sum_{j} \bar{X}_{j}^{B}\left(\beta_{j}^{A}-\beta_{j}^{B}\right)$

Equation (9) has a "three-fold" decomposition. The first component $U$ is the unexplained part of the differential captured by the shift coefficient. The second component $E$ is the portion attributable to differing endowments (quantity effect). The last component $\mathrm{C}$ is the portion of the differential attributable to differing coefficients. $E$ is the "explained part" of the decomposition, justified by certain worker characteristics associated with productivity, while $U+C$ is the "unexplained part", attributable to discrimination and also the potential effects of differences in unobserved variables and specification errors in the model (Jann, 2008; Esquivel, 2009). The Oaxaca-Blinder decomposition tells us that unobserved components are important but do not account for the bulk of wage differences. Nevertheless, the decomposition does not reveal whether what is at issue is classic discrimination by employers or unobserved heterogeneity in productivity associated with the performance of mothers.

\section{The Nopo wage gap decomposition}

The non-parametric matching-on-characteristics technique from Nopo (2008) is an alternative to the во decomposition. ${ }^{4}$ BO estimates earnings equations for all individuals in groups A and B without restricting itself to those with comparable characteristics, while Nopo (2008) takes into account the differences in the distribution of individuals' characteristics. Following Nopo (2008), we split the motherhood wage gap into four elements:

$$
\Delta=\left(\Delta_{x}+\Delta_{M}+\Delta_{N M}\right)+\Delta_{0}
$$

where $\Delta_{x}$ is the part of the wage gap that is explained by differences in the distribution of mothers' and nonmothers' characteristics over the common support (" $E$ " in the linear во decomposition), $\Delta_{M}$ is the part of the wage gap explained by differences in characteristics between the two groups of mothers (those who have characteristics that can be matched to non-mothers' characteristics and those who do not), $\Delta_{N M}$ is the part of

4 In explaining the Nopo decomposition we mostly follow Nopo (2008). 
the wage gap explained by differences in characteristics between the two groups of non-mothers (those who have characteristics that can be matched to mothers' characteristics and those who do not) and $\Delta_{0}$ is the "unexplained part" that cannot be accounted for by differences in the observable individual characteristics (" $U$ " in the linear во decomposition).

The matching procedure for estimating the four elements comprises the following steps. First, we select one mother from the sample without replacement. Second, we select all non-mothers who share the same characteristics as the mother selected in the first step. Third, we construct a synthetic

\section{IV}

\section{Data}

The data for this paper come from the Permanent Household Survey (EPH), a nationally representative survey carried out in 31 urban areas by the National Institute of Statistics and Censuses (INDEC). We evaluate the Greater Buenos Aires data. Since it is not possible to compare the same woman through the years, we use cross-sectional data from October surveys between 1995 and 2003. Changes in survey methodology meant that the series could not be continued beyond 2003; however, focusing on this time period does allow women's wage outcomes before and after the Argentine peso crisis (1995-1998 and 1999-2003, respectively) to be analysed. ${ }^{5}$

Because we are primarily interested in the relationship between segmented labour market dynamics and the motherhood penalty, we exclude women who are owners or employers, younger than 18 or older than 50 . We further restrict the sample to four different household situations for women: women who live alone, women who live with their husbands without children, women who live with their husbands and children, and women

\footnotetext{
5 The key differences are in the survey questions and sampling methodology. Prior to 2003, the survey was carried out twice a year, in May and October. Households were generally gone from the sample after two time periods. After 2003, the EPH was carried our four times a year, with respondent households being surveyed twice in two consecutive semesters in year 1 and twice in the same semesters in year 2 and again in year 3 before being rotated out of the sample. This shift should make it possible to do panel data analyses of post-2003 labour market data.
}

non-mother whose wage is the average of that for all the non-mothers in the second step and match her to the original mother. Fourth, we put both individuals (mother and synthetic non-mother) in a new sample of matched individuals. We then repeat the foregoing steps until we exhaust the original sample of mothers.

As a consequence of this matching algorithm, we obtain four sets of individuals: matched mothers, matched non-mothers, unmatched mothers and unmatched nonmothers. Notice that the sets of matched mothers and non-mothers show no difference in the distribution of characteristics. who live with their children without a husband. ${ }^{6} \mathrm{We}$ exclude extended families (those comprising more than the nuclear family) because it is not possible to identify from the survey which woman is the mother. ${ }^{7}$ One important constraint resulting from these exclusions is that lowincome women might be underrepresented in the survey, since they often live in households containing members of their extended families. ${ }^{8}$ Following this criterion and considering all women in the sample, the real monthly household income of the excluded subsample is 1,128 pesos, while that of the final subsample is 1,274 pesos. The average real hourly wage is 3.50 pesos for women in the excluded sample and 4.60 pesos for those in the final subsample. ${ }^{9}$

There are many ways to define employment in terms of formality and informality. In this article, the definition of informality follows the International Labour Organization

6 Working daughters aged over 18 are not included in the sample. 7 Since the individual survey does not contain information about which individual is the mother, we mapped the household and individual survey data to determine whether women were mothers and how many children under 15 they had.

8 The occurrence of extended families decreased by almost $33 \%$ between $1970(32.1 \%)$ and 1991 (21.5\%), however (Torrado, 2003, quoted by Faur, 2008).

9 We excluded 701 of a total female sample of 4,409 . The figures are in real Argentine pesos, adjusted for inflation using the consumer price index (CPI) deflator. As a reference, the United States dollar-Argentine peso exchange rate was 1.00 peso to US $\$ 1$ before $2002,3.40$ pesos to US\$ 1 in 2002 and 2.95 pesos to US\$ 1 in 2003 (Source: Central Bank of Argentina). 
(ILO) criteria and takes into account the enterprise-based definition (firm size) and the job-based definition (lack of registration). In the case of employees, we use the job-based definition, and the formal sector consists of employees who enjoy all legally mandated benefits, which may include pensions, paid vacations, workplace insurance, health insurance and Christmas bonuses. ${ }^{10}$ The informal sector includes employees who lack some or all of these legally mandated benefits plus all self-employed workers. Given that the EPH survey does not contain any questions about benefits for the self-employed, we base their inclusion in the informal sector on the firm size definition, and anyone working in a firm with less than five employees is also included in that sector. In this sample, $80 \%$ of the self-employed work by themselves and $20 \%$ work in firms of two to five employees. As a consistency check, we compared the two ILO definitions. In firms with less than six employees, roughly $10 \%$ of female employees obtained all legally mandated benefits. By contrast, only $21 \%$ of female employees working at firms with more than five employees stated that they lacked one or more legally mandated benefits. In other words, while $90 \%$ of women in firms with less than six employees did not receive full benefit packages, $80 \%$ of women in firms with six employees or more received full benefits. It appears that our use of small firms as an indirect measure of informal employment in the case of the self-employed is a reasonable assumption when it comes to the experience of women in the Argentine labour market. ${ }^{11}$

Table 1 shows the means, standard deviation and $\mathrm{t}$-difference test between the estimated means of the descriptive variables of formal versus informal women workers. ${ }^{12}$ Of a total of 3,733 women, 1,551 are formal workers and 2,182 are informal. There is a significant difference between the average real hourly wages of formal women (5.26 pesos) and informal women (4.16 pesos), and this is initial evidence for a segmented labour market, with formal workers earning more on average than informal workers. In the case of women in the formal sector subsample, $49 \%$ are mothers of at least one child aged under 15 , and of those mothers $28 \%$ have one child, $16 \%$ have two and $6 \%$ have three or more.

10 All legally mandated benefits included in the Employment Contract Act No. 20744.

${ }_{11}$ See Casal (2011) for further details on the definition of informality.

12 Table A.1 in the annex gives a detailed description of the variables used in this article. This section will describe only the main variables used for the research.
In the case of women working in the informal sector, $61 \%$ are mothers, $27 \%$ with one child, $20 \%$ with two and $14 \%$ with three or more. Note that this last category of mothers with three or more children is significantly larger for informal than for formal workers (14\% versus $6 \%$ ). As regards the age of the children, $28 \%$ of women in the formal sector and $32 \%$ in the informal sector have children aged under 5 , and $21 \%$ of formal and $29 \%$ of informal women have children aged between 6 and 14.

When education is considered, significant differences are found, especially between individuals with low and high levels of education: $12 \%$ of formal women have a low level of education, versus $42 \%$ of informal women, while the proportions with a high level of education are $40 \%$ and $15 \%$, respectively. This is evidence for a key factor driving labour market segmentation, which is explored in Casal (2011). When the husband's education is taken, it transpires that significantly more informal-sector women than formal-sector women married husbands with a low level of education, with significantly more formal-sector women marrying highly educated men. Where length of time in the same job is concerned, finally, the results were as expected, with formal workers averaging 7.81 years and informal workers 4.10 years. This initial evidence from the comparison of sample means shows that the formal and informal groups of women workers are statistically different in terms of wages, education, husband's education and length of time in the same job, and all these differences fit the segmented labour market hypothesis.

In analysing wage differentials between women in the following section, we undertake quantile regression estimations and describe the conditional real hourly wage distribution across different intervals of the formal- and informal-sector wage distributions. The two distributions are plotted in figures 1 and 2, and we use the two-sample Kolmogorov-Smirnov non-parametric test to compare the equality of distribution functions. From the results, it seems that we cannot accept the null hypothesis that the formal and informal real hourly wage distributions are drawn from the same distribution ( $\mathrm{p}$ value $=0$ ). A review of the charts suggests that the distributions are asymmetrical and most of the population is concentrated in the lower segments of the distribution, especially in the case of the informal sector. This finding supports the use of the quantile regressions, especially for consideration of issues related to glass ceilings at the top of the wage distribution and sticky floors, i.e., wage penalties at the bottom. 
TABLE 1

Argentina (Greater Buenos Aires): descriptive statistics, 1995-2003

(Sample means and standard deviations)

\begin{tabular}{|c|c|c|c|c|c|c|c|c|}
\hline \multirow{2}{*}{ Variable } & \multicolumn{2}{|c|}{$\begin{array}{c}\text { All } \\
\text { No }=3733\end{array}$} & \multicolumn{2}{|c|}{$\begin{array}{c}\text { Formal } \\
\text { No }=1551\end{array}$} & \multicolumn{2}{|c|}{$\begin{array}{c}\text { Informal } \\
\text { No }=2182\end{array}$} & \multicolumn{2}{|c|}{ Formal = Informal } \\
\hline & Mean & $\begin{array}{l}\text { Standard } \\
\text { deviation }\end{array}$ & Mean & $\begin{array}{l}\text { Standard } \\
\text { deviation }\end{array}$ & Mean & $\begin{array}{l}\text { Standard } \\
\text { deviation }\end{array}$ & $\begin{array}{l}\text { Difference } \\
\text { test }\end{array}$ & t-statistic \\
\hline dformal & 0.42 & 0.49 & & & & & & \\
\hline rhourwage & 4.62 & 4.08 & 5.26 & 3.56 & 4.16 & 4.39 & 1.10 & $8.03^{* * *}$ \\
\hline dmother & 0.56 & 0.50 & 0.49 & 0.50 & 0.61 & 0.49 & -0.11 & {$[-6.73]^{* * *}$} \\
\hline dmother_one & 0.27 & 0.45 & 0.28 & 0.45 & 0.27 & 0.44 & 0.01 & 0.13 \\
\hline dmother_two & 0.18 & 0.39 & 0.16 & 0.36 & 0.20 & 0.40 & -0.04 & {$[-3.00]^{* * *}$} \\
\hline dmother_more & 0.11 & 0.31 & 0.06 & 0.24 & 0.14 & 0.35 & -0.08 & {$[-7.32]^{* * *}$} \\
\hline dmother_5 & 0.30 & 0.46 & 0.28 & 0.45 & 0.32 & 0.47 & -0.05 & {$[-2.97]^{* *}$} \\
\hline dmother_6-14 & 0.26 & 0.44 & 0.22 & 0.41 & 0.28 & 0.45 & -0.07 & {$[-6.74]^{* * *}$} \\
\hline age & 36.69 & 8.15 & 36.56 & 8.08 & 36.77 & 8.24 & -0.21 & {$[-0.65]$} \\
\hline agesq & 1413 & 593 & 1402 & 592 & 1420 & 595 & -17.85 & {$[-0.76]$} \\
\hline dsingle & 0.12 & 0.32 & 0.13 & 0.34 & 0.11 & 0.31 & 0.02 & {$[1.67]^{*}$} \\
\hline dmarried & 0.74 & 0.44 & 0.73 & 0.44 & 0.74 & 0.44 & -0.01 & {$[-1.06]$} \\
\hline ddivorced & 0.14 & 0.35 & 0.14 & 0.35 & 0.15 & 0.35 & 0.00 & {$[-0.19]$} \\
\hline head & 0.27 & 0.44 & 0.28 & 0.45 & 0.26 & 0.44 & 0.02 & {$[-1.31]$} \\
\hline education1 & 0.29 & 0.46 & 0.12 & 0.32 & 0.42 & 0.49 & -0.30 & {$[-21.3]^{* * *}$} \\
\hline education2 & 0.46 & 0.50 & 0.48 & 0.50 & 0.43 & 0.50 & 0.05 & $3.23 * * *$ \\
\hline education3 & 0.25 & 0.43 & 0.40 & 0.49 & 0.15 & 0.35 & 0.25 & $18.23 * * *$ \\
\hline yearsinjob & 5.61 & 7.11 & 7.81 & 7.46 & 4.10 & 6.75 & 3.71 & $16.43^{* * *}$ \\
\hline dfulltime & 0.69 & 0.46 & 0.84 & 0.37 & 0.59 & 0.49 & 0.24 & $16.40^{* * *}$ \\
\hline dparttime & 0.31 & 0.46 & 0.16 & 0.37 & 0.41 & 0.49 & -0.24 & {$[-16.45] * * *$} \\
\hline dpublic & 0.20 & 0.40 & 0.35 & 0.48 & 0.08 & 0.28 & 0.27 & $22.04 * * *$ \\
\hline dprivate & 0.80 & 0.40 & 0.65 & 0.48 & 0.91 & 0.28 & -0.27 & {$[-22.05] * * *$} \\
\hline dfirm_small & 0.33 & 0.47 & 0.02 & 0.12 & 0.55 & 0.50 & -0.53 & {$[-41.21] * * *$} \\
\hline dfirm_medium & 0.15 & 0.36 & 0.08 & 0.28 & 0.20 & 0.40 & -0.12 & {$[-9.88]^{* * *}$} \\
\hline dfirm_large & 0.49 & 0.50 & 0.86 & 0.35 & 0.22 & 0.41 & 0.64 & $50.61 * * *$ \\
\hline dmanufacturing & 0.13 & 0.33 & 0.12 & 0.32 & 0.14 & 0.34 & -0.02 & {$[-1.44]$} \\
\hline dcommerce & 0.16 & 0.36 & 0.11 & 0.32 & 0.19 & 0.39 & -0.07 & {$[-5.97] * * *$} \\
\hline dservice & 0.72 & 0.45 & 0.77 & 0.42 & 0.68 & 0.47 & 0.09 & $5.88 * * *$ \\
\hline manager & 0.04 & 0.20 & 0.09 & 0.28 & 0.01 & 0.12 & 0.07 & $11.53^{* * *}$ \\
\hline professional & 0.09 & 0.28 & 0.09 & 0.29 & 0.08 & 0.27 & 0.01 & 1.43 \\
\hline administrative & 0.33 & 0.47 & 0.58 & 0.49 & 0.15 & 0.35 & 0.43 & $31.49 * * *$ \\
\hline service & 0.52 & 0.50 & 0.23 & 0.42 & 0.74 & 0.44 & -0.51 & {$[-36.11] * * *$} \\
\hline bluecollar & 0.02 & 0.14 & 0.01 & 0.12 & 0.02 & 0.15 & -0.01 & {$[-1.64]^{*}$} \\
\hline
\end{tabular}

Source: prepared by the authors on the basis of the Permanent Household Survey (EPH).

Note: for an explanation of the variables, see table A.1 of the annex.

* Significant at 10\%.** Significant at 5\%.*** Significant at $1 \%$. 
FIGURE 1

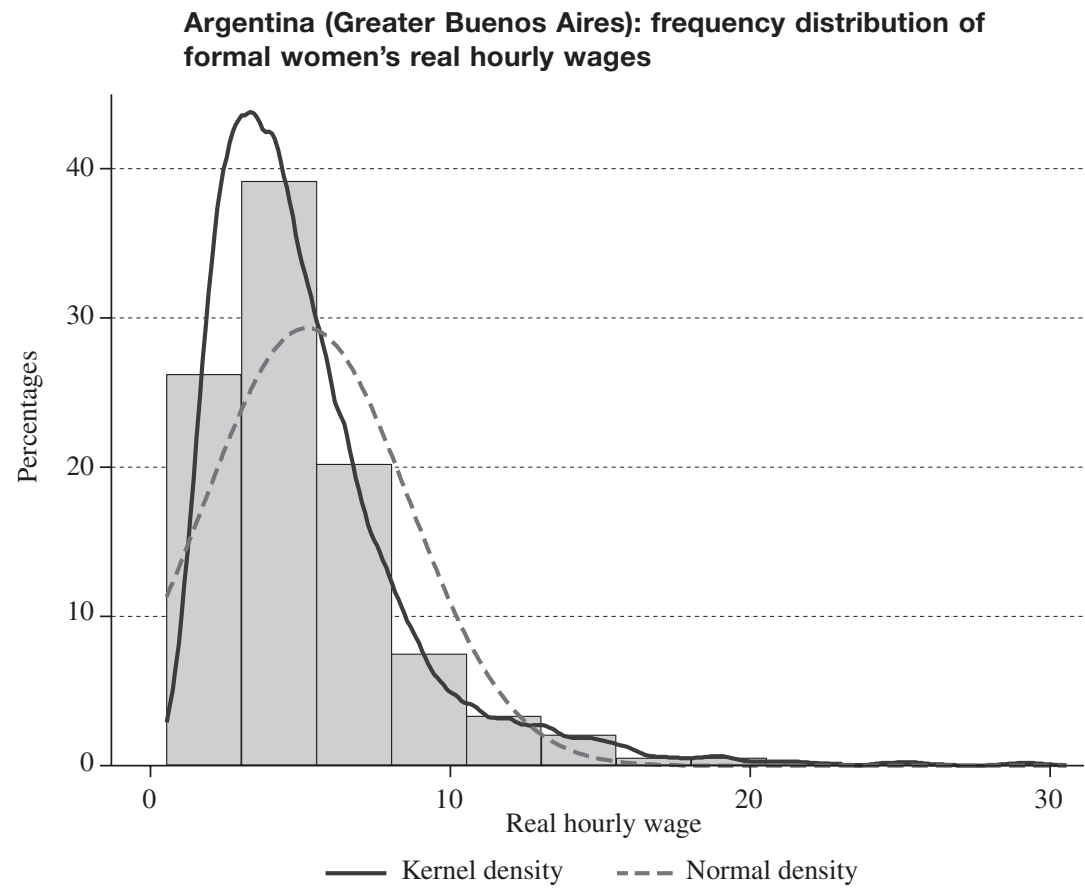

Source: prepared by the authors on the basis of the Permanent Household Survey (EPH).

FIGURE 2

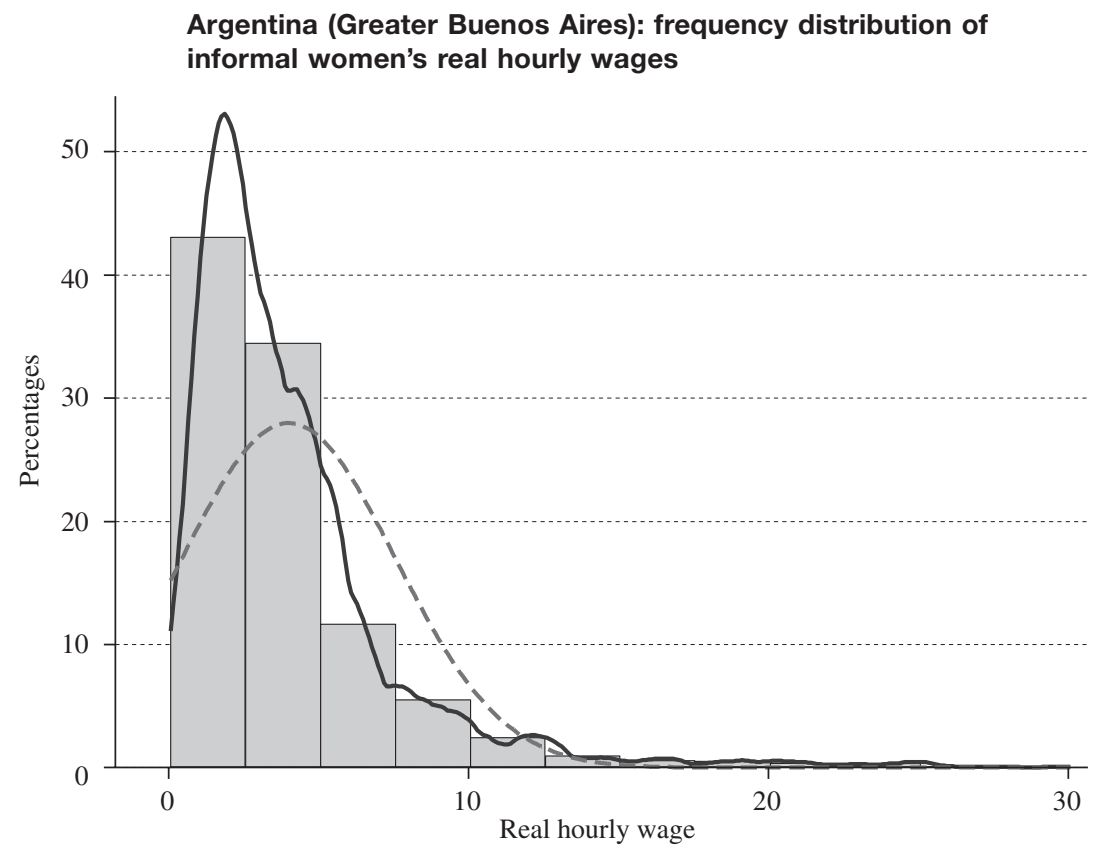

Kernel density - - - Normal density

Source: prepared by the authors on the basis of the Permanent Household Survey (EPH). 


\section{$\mathrm{V}$}

\section{Results}

Tables 2 to 4 report the estimated earnings functions for oLs and quantile regressions. The wage estimations in table 2 include an analysis of all women together and then separate wage estimations for the formal and informal sectors. As a starting point for discussing the results, we note that most of the estimated coefficients for control variables in table 2 are significant, and the selected variables seem to explain wages in a manner consistent with conventional Mincerian estimation efforts. ${ }^{13}$ As an example, for the education indicator variables, the highest wage premiums are for those who have completed university.

In all the estimation results, the empirical evidence supports the traditional segmented labour market hypothesis that women working in the informal sector earn significantly less than their formal-sector counterparts. On the evidence of table 2, there is a wage premium in the formal segment of about $16 \%$. When we examine the oLs results for all women together and do not differentiate between the informal and formal sectors, we find a motherhood wage penalty that increases with the number of children (3.8\% for one child, $9.6 \%$ for two children and $19.4 \%$ for three or more children).

More telling are the econometric results that emerge when we examine the two market segments separately. As predicted, the estimated coefficients associated with motherhood and children are not significant in the formal sector. In other words, the hypothesis that there would not be a motherhood wage penalty in the formal sector is consistent with the empirical evidence. By contrast, women in the informal sector experience a statistically significant motherhood wage penalty in all of the specifications. We find that the wage penalty is not the same for all mothers, as having more children increases the estimated penalty ( $7.8 \%$ for one child, $15.5 \%$ for two children and $26.3 \%$ for three or more children).

In 1999, following the 1998 international crisis in East Asia, Brazil and Russia, Argentina's GDP fell by $3.4 \%$ and the country entered an all-out recession which lasted until July 2002, according to the National Institute of Statistics and Censuses (INDEC). Table 3

13 Note that all the results have to be interpreted in relation to the base category: a blue-collar single woman, non-mother, public employee with less than complete secondary education, employed full-time at a small services firm. presents the whole period under study and also splits the sample into the subperiods before and after the shock: 1995-1998 and 1999-2003. The coefficient estimates for the motherhood wage penalty, as reported in table 3 , appear to be relatively stable over time, showing a higher penalty in the period before the shock $(10.1 \%$ versus $5.7 \%$ for one child, $16.4 \%$ versus $13.1 \%$ for two children and $27.3 \%$ versus $26.0 \%$ for three or more children). The estimated coefficients associated with motherhood and children are non-significant across all the formal-sector regressions.

The quantile regression results in table 4 offer a closer look at the motherhood wage penalty across the wage distribution. As in the oLs results, formal-sector women workers do not experience statistically significant motherhood wage penalties. Across the full time period of the data, two different specifications of motherhood (one by the number of children and one by their age) show no significant wage penalties for mothers working in the formal sector. Overall, the quantile regression results for formal-sector women confirm the absence of a wage penalty for motherhood.

By contrast, mothers in the informal sector do experience statistically significant wage penalties, and those penalties are greatest for women in the lower wage quantiles. For example, the penalty for having three or more children in the informal sector is greatest at the bottom of the conditional wage distribution, with the poorest mothers (tenth percentile) experiencing a penalty of $44.8 \%$ and those in the richest quantile (ninetieth percentile) one of $13.5 \%$. The pattern of the penalty is different for mothers of two children, for whom both the glass ceiling and sticky floor hypotheses seem to apply, as the penalty decreases up the wage distribution from $17.5 \%$ at the tenth percentile to $17.3 \%$ at the twentyfifth, $10.7 \%$ at the fiftieth and $8.8 \%$ at the seventy-fifth, but then increases again at the ninetieth percentile to $16.1 \%$. In the case of mothers with one child, the wage penalty is between $3.9 \%$ and $9.5 \%$, but the coefficients are generally not significant, the exception being the largest difference at the twenty-fifth percentile, where women with one child earn $9.5 \%$ less than non-mothers. One way of summarizing the motherhood wage penalty for informal-sector women is that it increases with the number of children and is likely to be greatest at the bottom of the wage spectrum. 
TABLE 2

Argentina (Greater Buenos Aires): ordinary least squares (OLS) earnings function, 1995-2003

\begin{tabular}{|c|c|c|c|}
\hline Dependent variable: natural log of real hourly wages & All & Formal & Informal \\
\hline dformal & $\begin{array}{l}0.157 \\
{[0.028]^{* * *}}\end{array}$ & & \\
\hline dmother_one & $\begin{array}{l}-0.038 \\
{[0.026]}\end{array}$ & $\begin{array}{l}-0.004 \\
{[0.030]}\end{array}$ & $\begin{array}{l}-0.078 \\
{[0.038]^{* *}}\end{array}$ \\
\hline dmother_two & $\begin{array}{l}-0.096 \\
{[0.033]^{* * *}}\end{array}$ & $\begin{array}{l}-0.017 \\
{[0.040]}\end{array}$ & $\begin{array}{l}-0.155 \\
{[0.046]^{* * *}}\end{array}$ \\
\hline dmother_more & $\begin{array}{l}-0.194 \\
{[0.041]^{* * *}}\end{array}$ & $\begin{array}{c}0.009 \\
{[0.045]}\end{array}$ & $\begin{array}{l}-0.263 \\
{[0.054]^{* * *}}\end{array}$ \\
\hline age & $\begin{array}{l}0.028 \\
{[0.012]^{* *}}\end{array}$ & $\begin{array}{c}0.020 \\
{[0.016]}\end{array}$ & $\begin{array}{l}0.038 \\
{[0.017]^{* *}}\end{array}$ \\
\hline agesquared & $\begin{array}{c}0.000 \\
{[0.000]^{* *}}\end{array}$ & $\begin{array}{c}0.000 \\
{[0.000]}\end{array}$ & $\begin{array}{c}0.000 \\
{[0.000]^{* *}}\end{array}$ \\
\hline dmarried & $\begin{array}{c}0.011 \\
{[0.041]}\end{array}$ & $\begin{array}{c}0.074 \\
{[0.060]}\end{array}$ & $\begin{array}{l}-0.047 \\
{[0.054]}\end{array}$ \\
\hline ddivorced & $\begin{array}{l}-0.066 \\
{[0.041]}\end{array}$ & $\begin{array}{c}0.059 \\
{[0.051]}\end{array}$ & $\begin{array}{l}-0.180 \\
{[0.058]^{* * *}}\end{array}$ \\
\hline head of household & $\begin{array}{c}0.092 \\
{[0.036]^{* *}}\end{array}$ & $\begin{array}{c}0.067 \\
{[0.054]}\end{array}$ & $\begin{array}{l}0.095 \\
{[0.047]^{* *}}\end{array}$ \\
\hline education2 & $\begin{array}{l}0.189 \\
{[0.029]^{* * *}}\end{array}$ & $\begin{array}{l}0.319 \\
{[0.037]^{* * *}}\end{array}$ & $\begin{array}{l}0.157 \\
{[0.035]^{* * *}}\end{array}$ \\
\hline education3 & $\begin{array}{l}0.532 \\
{[0.039]^{* * *}}\end{array}$ & $\begin{array}{l}0.589 \\
{[0.043]^{* * *}}\end{array}$ & $\begin{array}{l}0.724 \\
{[0.072]^{* * *}}\end{array}$ \\
\hline dprivate & $\begin{array}{l}0.233 \\
{[0.027]^{* * *}}\end{array}$ & $\begin{array}{l}0.083 \\
{[0.028]^{* * *}}\end{array}$ & $\begin{array}{c}0.321 \\
{[0.055]^{* * *}}\end{array}$ \\
\hline yearsinjob & $\begin{array}{l}0.015 \\
{[0.002]^{* * *}}\end{array}$ & $\begin{array}{l}0.009 \\
{[0.002]^{* * *}}\end{array}$ & $\begin{array}{l}0.018 \\
{[0.004]^{* * *}}\end{array}$ \\
\hline dfirm_medium & $\begin{array}{l}-0.005 \\
{[0.039]}\end{array}$ & $\begin{array}{l}-0.014 \\
{[0.064]}\end{array}$ & $\begin{array}{c}0.085 \\
{[0.046]^{*}}\end{array}$ \\
\hline dfirm_large & $\begin{array}{c}0.033 \\
{[0.033]}\end{array}$ & $\begin{array}{c}0.003 \\
{[0.052]}\end{array}$ & $\begin{array}{c}0.130 \\
{[0.046]^{* * *}}\end{array}$ \\
\hline dmanufacturing & $\begin{array}{l}-0.280 \\
{[0.039]^{* * *}}\end{array}$ & $\begin{array}{c}0.046 \\
{[0.043]}\end{array}$ & $\begin{array}{l}-0.488 \\
{[0.053]^{* * *}}\end{array}$ \\
\hline dcommerce & $\begin{array}{l}-0.354 \\
{[0.037]^{* * *}}\end{array}$ & $\begin{array}{l}-0.133 \\
{[0.044]^{* * *}}\end{array}$ & $\begin{array}{l}-0.478 \\
{[0.049]^{* * *}}\end{array}$ \\
\hline dparttime & $\begin{array}{c}0.434 \\
{[0.026]^{* * *}}\end{array}$ & $\begin{array}{l}0.191 \\
{[0.035]^{* * *}}\end{array}$ & $\begin{array}{c}0.549 \\
{[0.032]^{* * *}}\end{array}$ \\
\hline manager & $\begin{array}{l}0.793 \\
{[0.095]^{* * *}}\end{array}$ & $\begin{array}{l}0.689 \\
{[0.103]^{* * *}}\end{array}$ & $\begin{array}{l}0.873 \\
{[0.169]^{* * *}}\end{array}$ \\
\hline professional & $\begin{array}{l}0.752 \\
{[0.093]^{* * *}}\end{array}$ & $\begin{array}{l}0.636 \\
{[0.105]^{* * *}}\end{array}$ & $\begin{array}{c}0.622 \\
{[0.130]^{* * *}}\end{array}$ \\
\hline administrative & $\begin{array}{l}0.415 \\
{[0.083]^{* * * *}}\end{array}$ & $\begin{array}{l}0.315 \\
{[0.093] * * *}\end{array}$ & $\begin{array}{l}0.422 \\
{[0.111]^{* * *}}\end{array}$ \\
\hline service & $\begin{array}{l}0.187 \\
{[0.080]^{* *}}\end{array}$ & $\begin{array}{c}0.046 \\
{[0.091]}\end{array}$ & $\begin{array}{l}0.276 \\
{[0.101]^{* * *}}\end{array}$ \\
\hline year & $\begin{array}{l}-0.052 \\
{[0.005]^{* * *}}\end{array}$ & $\begin{array}{l}-0.024 \\
{[0.006]^{* * *}}\end{array}$ & $\begin{array}{l}-0.070 \\
{[0.007] * * *}\end{array}$ \\
\hline constant & $\begin{array}{l}103.462 \\
{[9.422]^{* * *}}\end{array}$ & $\begin{array}{l}47.365 \\
{[11.274]^{* * *}}\end{array}$ & $\begin{array}{l}139.429 \\
{[13.588]^{* * * *}}\end{array}$ \\
\hline $\begin{array}{l}\text { Observations } \\
\mathrm{R}^{2}\end{array}$ & $\begin{array}{c}3707 \\
0.440\end{array}$ & $\begin{array}{c}1560 \\
0.410\end{array}$ & $\begin{array}{c}2147 \\
0.440\end{array}$ \\
\hline
\end{tabular}

Source: prepared by the authors on the basis of the Permanent Household Survey (EPH).

Note: for an explanation of the variables, see table A.1 of the annex. The standard errors are listed below the estimates in brackets, and are robust to heteroskedasticity. The reference category is a blue-collar single woman with less than complete secondary education, employed full-time at a small services firm, public worker and non-mother.

* Significant at $10 \%$. ** Significant at $5 \%$. *** Significant at $1 \%$. 
TABLE 3

Argentina (Greater Buenos Aires): ordinary least squares (OLS) earnings function before and after the shock, 1995-2003

\begin{tabular}{|c|c|c|c|c|c|c|}
\hline & \multicolumn{2}{|c|}{$1995-2003$} & \multicolumn{2}{|c|}{ 1995-1998 (pre-shock) } & \multicolumn{2}{|c|}{ 1999-2003 (post-shock) } \\
\hline & Formal & Informal & Formal & Informal & Formal & Informal \\
\hline \multirow[t]{2}{*}{ Mother of one child } & -0.004 & $-0.078 * *$ & -0.051 & $-0.101^{*}$ & 0.040 & -0.057 \\
\hline & $(0.030)$ & $(0.038)$ & $(0.042)$ & $(0.052)$ & $(0.044)$ & $(0.055)$ \\
\hline \multirow[t]{2}{*}{ Mother of two children } & -0.017 & $-0.155^{* * *}$ & -0.077 & $-0.164 * * *$ & 0.022 & $-0.131^{*}$ \\
\hline & $(0.040)$ & $(0.046)$ & $(0.054)$ & $(0.060)$ & $(0.058)$ & $(0.067)$ \\
\hline \multirow[t]{2}{*}{ Mother of three or more children } & 0.009 & $-0.263 * * *$ & -0.045 & $-0.273 * * *$ & 0.036 & $-0.260 * * *$ \\
\hline & $(0.045)$ & $(0.054)$ & $(0.061)$ & $(0.072)$ & $(0.066)$ & $(0.077)$ \\
\hline $\mathrm{R}^{2}$ & 0.415 & 0.443 & 0.400 & 0.442 & 0.461 & 0.440 \\
\hline Observations & 1560 & 2147 & 825 & 1069 & 735 & 1078 \\
\hline \multirow[t]{2}{*}{ Mother of child aged under 6} & -0.002 & $-0.180 * * *$ & -0.032 & $-0.232 * * *$ & 0.017 & $-0.139 * *$ \\
\hline & $(0.032)$ & $(0.042)$ & $(0.043)$ & $(0.055)$ & $(0.046)$ & $(0.061)$ \\
\hline \multirow[t]{2}{*}{ Mother of child aged 6 to 14} & -0.013 & $-0.099 * *$ & $-0.087 *$ & $-0.090 *$ & 0.055 & $-0.094 *$ \\
\hline & $(0.033)$ & $(0.039)$ & $(0.045)$ & $(0.053)$ & $(0.048)$ & $(0.056)$ \\
\hline $\mathrm{R}^{2}$ & 0.415 & 0.441 & 0.400 & 0.443 & 0.461 & 0.436 \\
\hline Observations & 1560 & 2147 & 825 & 1069 & 735 & 1078 \\
\hline
\end{tabular}

Source: prepared by the authors on the basis of the Permanent Household Survey (EPH).

Note: the standard errors are listed below the estimates in brackets, and are robust to heteroskedasticity. The reference category is a blue-collar single woman with less than complete secondary education who is a non-mother, public worker and is employed full-time at a small services firm. The control variables are the same as in table 2 .

* Significant at $10 \%$.** Significant at $5 \%$.*** Significant at $1 \%$.

The quantile regression results were also disaggregated by time period, pre- and post-peso crisis. The results (also depicted in table 4) do not differ much from those just described. There is some evidence of a motherhood wage penalty among the lowest quantile of formal-sector women in the pre-crisis period that is not there later. Otherwise, across the rest of the formal-sector quantiles, there are no statistically significant motherhood wage penalty effects in either of the two time periods. The informal sector, however, shows strong evidence in both time periods of motherhood wage penalties that are of similar size and statistical significance across the quantiles, with the largest penalties being experienced by women with three or more children. As in the ols results, the penalty is greater in the preshock period. The differences in the coefficients before and after the shock are not significant, but a larger gap prior to the crisis could reflect general downward pressure on wages affecting the formal sector during this period. 
Argentina (Greater Buenos Aires): quantile regression earnings function, 1995-2003

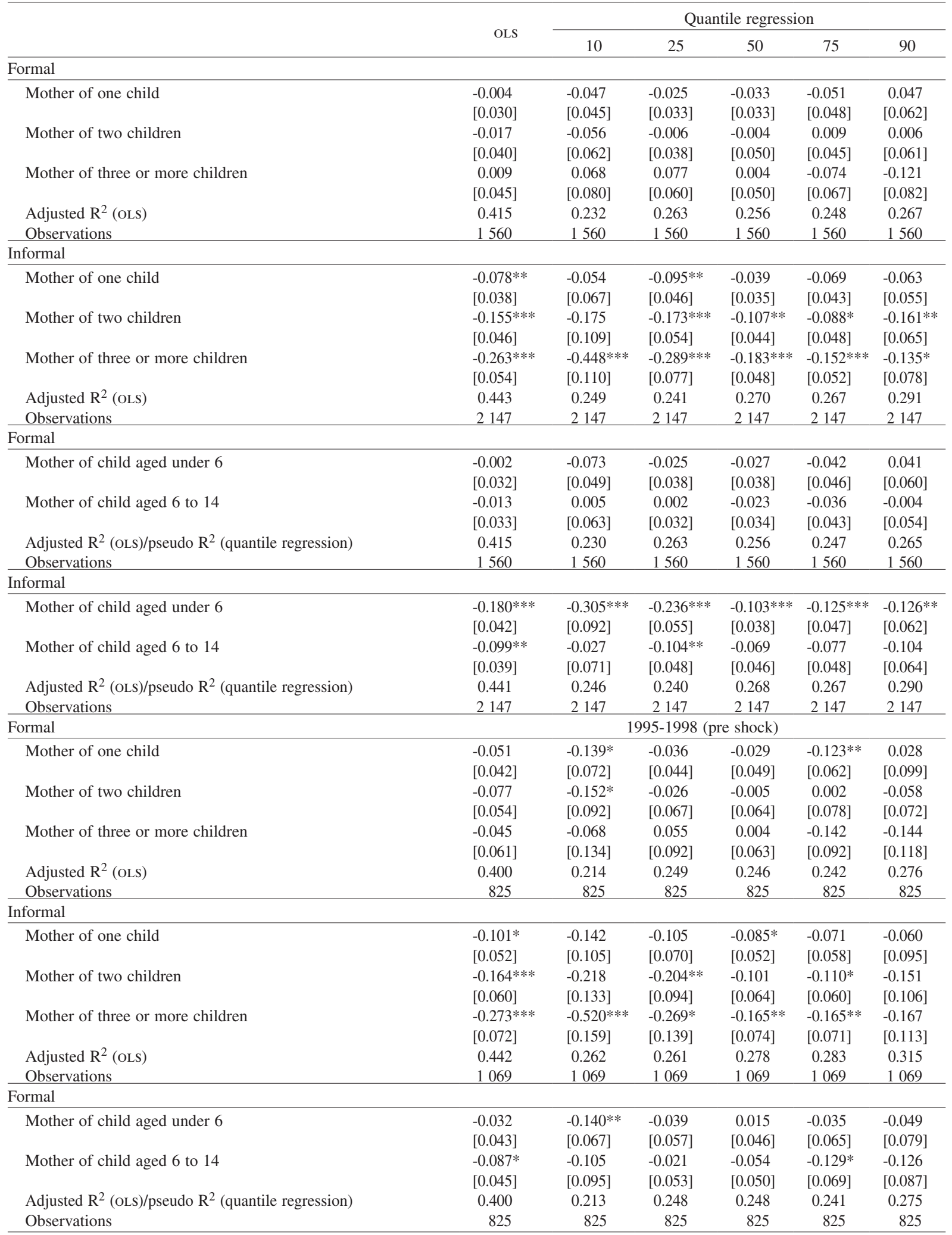




\begin{tabular}{|c|c|c|c|c|c|c|}
\hline \multirow{3}{*}{ Informal } & \multirow{2}{*}{ OLS } & \multicolumn{5}{|c|}{ Quantile regression } \\
\hline & & \multirow[t]{2}{*}{10} & \multirow[t]{2}{*}{25} & \multirow[t]{2}{*}{50} & \multirow[t]{2}{*}{75} & \multirow[t]{2}{*}{90} \\
\hline & & & & & & \\
\hline Mother of child aged under 6 & $\begin{array}{l}-0.232^{* * * *} \\
{[0.055]}\end{array}$ & $\begin{array}{l}-0.372 * * * \\
{[0.125]}\end{array}$ & $\begin{array}{l}-0.266^{* * *} \\
{[0.080]}\end{array}$ & $\begin{array}{l}-0.129 * * \\
{[0.056]}\end{array}$ & $\begin{array}{l}-0.143 * * * \\
{[0.049]}\end{array}$ & $\begin{array}{l}-0.172^{* *} \\
{[0.078]}\end{array}$ \\
\hline Mother of child aged 6 to 14 & $\begin{array}{l}-0.090^{*} \\
{[0.053]}\end{array}$ & $\begin{array}{l}-0.106 \\
{[0.099]}\end{array}$ & $\begin{array}{l}-0.101 \\
{[0.070]}\end{array}$ & $\begin{array}{l}-0.098^{*} \\
{[0.055]}\end{array}$ & $\begin{array}{l}-0.094 \\
{[0.065]}\end{array}$ & $\begin{array}{l}-0.089 \\
{[0.092]}\end{array}$ \\
\hline Adjusted $\mathrm{R}^{2}$ (oLs)/pseudo $\mathrm{R}^{2}$ (quantile regression) & 0.443 & 0.258 & 0.263 & 0.278 & 0.282 & 0.314 \\
\hline Observations & 1069 & 1069 & 1069 & 1069 & 1069 & 1069 \\
\hline Formal & \multicolumn{6}{|c|}{ 1999-2003 (post-shock) } \\
\hline Mother of one child & $\begin{array}{c}0.040 \\
{[0.044]}\end{array}$ & $\begin{array}{c}0.024 \\
{[0.075]}\end{array}$ & $\begin{array}{c}0.023 \\
{[0.051]}\end{array}$ & $\begin{array}{c}0.012 \\
{[0.058]}\end{array}$ & $\begin{array}{c}0.056 \\
{[0.068]}\end{array}$ & $\begin{array}{c}0.037 \\
{[0.070]}\end{array}$ \\
\hline Mother of two children & $\begin{array}{c}0.022 \\
{[0.058]}\end{array}$ & $\begin{array}{c}0.038 \\
{[0.086]}\end{array}$ & $\begin{array}{c}0.042 \\
{[0.061]}\end{array}$ & $\begin{array}{c}0.004 \\
{[0.065]}\end{array}$ & $\begin{array}{c}0.033 \\
{[0.091]}\end{array}$ & $\begin{array}{l}-0.017 \\
{[0.097]}\end{array}$ \\
\hline Mother of three or more children & $\begin{array}{c}0.036 \\
{[0.066]}\end{array}$ & $\begin{array}{c}0.042 \\
{[0.116]}\end{array}$ & $\begin{array}{c}0.051 \\
{[0.095]}\end{array}$ & $\begin{array}{c}0.035 \\
{[0.101]}\end{array}$ & $\begin{array}{l}-0.053 \\
{[0.115]}\end{array}$ & $\begin{array}{l}-0.131 \\
{[0.113]}\end{array}$ \\
\hline Adjusted $\mathrm{R}^{2}$ (oLs) & 0.461 & 0.295 & 0.302 & 0.291 & 0.276 & 0.289 \\
\hline Observations & 735 & 735 & 735 & 735 & 735 & 735 \\
\hline \multicolumn{7}{|l|}{ Informal } \\
\hline Mother of one child & $\begin{array}{l}-0.057 \\
{[0.055]}\end{array}$ & $\begin{array}{c}0.060 \\
{[0.099]}\end{array}$ & $\begin{array}{l}-0.119^{*} \\
{[0.067]}\end{array}$ & $\begin{array}{c}0.012 \\
{[0.056]}\end{array}$ & $\begin{array}{l}-0.058 \\
{[0.065]}\end{array}$ & $\begin{array}{l}-0.096 \\
{[0.089]}\end{array}$ \\
\hline Mother of two children & $\begin{array}{l}-0.131^{*} \\
{[0.067]}\end{array}$ & $\begin{array}{l}-0.170 \\
{[0.164]}\end{array}$ & $\begin{array}{l}-0.188^{* *} \\
{[0.076]}\end{array}$ & $\begin{array}{l}-0.068 \\
{[0.069]}\end{array}$ & $\begin{array}{l}-0.084 \\
{[0.083]}\end{array}$ & $\begin{array}{l}-0.130 \\
{[0.089]}\end{array}$ \\
\hline Mother of three or more children & $\begin{array}{l}-0.260 * * * * \\
{[0.077]}\end{array}$ & $\begin{array}{l}-0.451 * * \\
{[0.191]}\end{array}$ & $\begin{array}{l}-0.279^{* *} \\
{[0.117]}\end{array}$ & $\begin{array}{l}-0.212 * * \\
{[0.090]}\end{array}$ & $\begin{array}{l}-0.151^{*} \\
{[0.092]}\end{array}$ & $\begin{array}{l}-0.149 \\
{[0.104]}\end{array}$ \\
\hline Adjusted $\mathrm{R}^{2}$ (oLs) & 0.440 & 0.254 & 0.234 & 0.268 & 0.269 & 0.282 \\
\hline Observations & 1078 & 1078 & 1078 & 1078 & 1078 & 1078 \\
\hline \multicolumn{7}{|l|}{ Formal } \\
\hline Mother of child aged under 6 & $\begin{array}{c}0.017 \\
{[0.046]}\end{array}$ & $\begin{array}{c}0.017 \\
{[0.076]}\end{array}$ & $\begin{array}{l}-0.012 \\
{[0.055]}\end{array}$ & $\begin{array}{l}-0.010 \\
{[0.064]}\end{array}$ & $\begin{array}{l}-0.009 \\
{[0.073]}\end{array}$ & $\begin{array}{c}0.092 \\
{[0.082]}\end{array}$ \\
\hline Mother of child aged 6 to 14 & $\begin{array}{c}0.055 \\
{[0.048]}\end{array}$ & $\begin{array}{c}0.092 \\
{[0.081]}\end{array}$ & $\begin{array}{c}0.070 \\
{[0.061]}\end{array}$ & $\begin{array}{c}0.033 \\
{[0.050]}\end{array}$ & $\begin{array}{c}0.077 \\
{[0.059]}\end{array}$ & $\begin{array}{c}0.043 \\
{[0.072]}\end{array}$ \\
\hline Adjusted $\mathrm{R}^{2}$ (oLs)/pseudo $\mathrm{R}^{2}$ (quantile regression) & 0.461 & 0.296 & 0.304 & 0.292 & 0.276 & 0.288 \\
\hline Observations & 735 & 735 & 735 & 735 & 735 & 735 \\
\hline \multicolumn{7}{|l|}{ Informal } \\
\hline Mother of child aged under 6 & $\begin{array}{l}-0.139 * * \\
{[0.061]}\end{array}$ & $\begin{array}{l}-0.215 \\
{[0.134]}\end{array}$ & $\begin{array}{l}-0.162 * * \\
{[0.079]}\end{array}$ & $\begin{array}{l}-0.119 * * \\
{[0.059]}\end{array}$ & $\begin{array}{l}-0.044 \\
{[0.076]}\end{array}$ & $\begin{array}{l}-0.085 \\
{[0.080]}\end{array}$ \\
\hline Mother of child aged 6 to 14 & $\begin{array}{l}-0.094^{*} \\
{[0.056]}\end{array}$ & $\begin{array}{l}-0.043 \\
{[0.098]}\end{array}$ & $\begin{array}{l}-0.138^{* *} \\
{[0.067]}\end{array}$ & $\begin{array}{l}-0.055 \\
{[0.054]}\end{array}$ & $\begin{array}{l}-0.047 \\
{[0.066]}\end{array}$ & $\begin{array}{l}-0.145^{*} \\
{[0.082]}\end{array}$ \\
\hline Adjusted $\mathrm{R}^{2}$ (OLS)/pseudo $\mathrm{R}^{2}$ (quantile regression) & 0.436 & 0.247 & 0.231 & 0.265 & 0.267 & 0.283 \\
\hline Observations & 1078 & 1078 & 1078 & 1078 & 1078 & 1078 \\
\hline
\end{tabular}

Source: prepared by the authors on the basis of the Permanent Household Survey (EPH).

Note: the standard errors are listed below the estimates in brackets, and are robust to heteroskedasticity. The standard errors for the quantile regressions are computed using data analysis and statistical software (STATA) and are based on 100 bootstrap replications. The reference category is a blue-collar single woman with less than complete secondary education who is a non-mother, public worker and is employed full-time at a small services firm. The control variables are the same as in table 2 .

* Significant at 10\%.** Significant at 5\%.*** Significant at $1 \%$.

\section{Another look at the motherhood wage penalty}

So far, we have carefully examined variations in the motherhood wage penalty by the number of children. An alternative approach is to consider penalties associated with the age of children or the timing of childbearing. Because childcare requirements are related to the age of children, different patterns may emerge for mothers of young as opposed to older children, especially considering that enrolment in a kindergarten is mandatory in Argentina when a child turns 5. ${ }^{14}$ Accordingly, we redivided the sample into groups of mothers of children aged under 6 , mothers of children aged between 6 and

14 Article 16 of the National Education Act, No. 26206, provides that school is compulsory from the age of five. 
14 , and non-mothers, and then repeated the estimations (tables 3 and 4).

As before, there is no concrete evidence of a motherhood wage penalty in the formal sector, while the coefficients for motherhood penalties are significant in the informal subsample. For instance, table 3 shows that having a child aged under 6 is associated with a penalty of $18 \%$, while in the case of older children the wage penalty is $9.9 \%$ (OLs). If the periods before and after the economic shock are considered separately, the penalty seems to have been relatively stable over time in the case of mothers of older children (9\%), decreasing however from $23.2 \%$ in $1995-1998$ to $13.9 \%$ in 1999 2003 for mothers of younger children.

The quantile regression estimates in table 4 indicate significant wage differences associated with motherhood in the informal sector over the wage distribution. For mothers of children aged under 6 , the penalty is $30.5 \%$ in the tenth percentile, $23.6 \%$ in the twenty-fifth, $10.3 \%$ in the fiftieth, $12.5 \%$ in the seventy-fifth and $12.6 \%$ in the ninetieth, again offering supporting evidence for the sticky floor hypothesis in the informal sector. In the case of mothers of older children, meanwhile, only one coefficient estimate is significant, namely that for the twenty-fifth quantile (10.4\%). The informal sector shows strong evidence in both time periods (pre- and post-crisis) for motherhood wage penalties across the quantiles, with the largest penalties being experienced by women with children aged under 6 .

As might be expected, then, the motherhood wage penalty is greater when children are younger. Nevertheless, as Budig and England (2001) highlight, it could be the case that mothers, and especially mothers of children who are not old enough to go to school, seek "motherfriendly" jobs. In other words, they may be looking for less taxing jobs with flexible hours, few travel requirements and other mother-friendly attributes. If those mothers are more willing than others to take these mother-friendly jobs, they will earn less. In the case of Argentina, Faur (2011) indicates that implementation of crèches for the children of working parents has never been widespread in Argentina: coverage of five-year-old children has been extended but State provision of educational services for children under 3 is still limited throughout the country, so that households with younger children need the help of family members or private care providers. In the 1990s, the inadequacy of State-run childcare services resulted in the expansion of community crèches and private childcare facilities (Faur, 2011). The consequence was a widening of the gap between women in poor families and those in middle- to high-income ones. Women from middle- and high-income households normally have greater scope to integrate work in the marketplace with family responsibilities by defamilializing care, given their greater access to institutionalized public or private care services of various kinds, or by engaging domestic helpers. For their part, women in lower-income sectors might stay at home and care for their children, participate in community arrangements to secure food and services for them, or join the labour market and secure child care (Faur, 2011).

If a comparison is made with the empirical results from the other papers mentioned in section II, the magnitude of the motherhood wage penalty for informal-sector female workers is invariably larger than it is in other countries where the empirical analyses do not control for formality. However, it also seems to be important to consider the evolution of female labour force participation, fertility patterns and the increasing probability that a woman will have her first baby at an older age. The ideal estimation would be a double selection model covering the probability of being in the labour force and of being a mother and taking account of sample selection as well as the endogeneity of the choice to become a mother. Unfortunately, we cannot estimate this model because it requires at least two instrumental variables that were not available in our survey. Additionally, given the characteristics of the EPH survey, it is not possible to identify patterns of delayed childbirth because there is no information about the age of the oldest child in the case of women with children aged over 14 . The best approximation is to consider the same set of wage regressions but look at different female age cohorts. ${ }^{15}$ When this is done, the findings suggest that younger cohorts of mothers are likely to experience a higher wage penalty than older mothers.

\section{The Blinder-Oaxaca decomposition}

We are interested in comparing earnings between groups, and the Blinder-Oaxaca decomposition can be used to divide the wage differential between two groups into the "explained part", justified by certain worker characteristics associated with productivity, and the "unexplained part", which may be attributable to discrimination but also to the potential effects of differences in unobserved variables and specification

15 The regressions are available upon request, but the results are in many cases not significant. 
errors in the model (Jann, 2008; Esquivel, 2009). ${ }^{16}$ Table 5 illustrates the Blinder-Oaxaca decomposition for the main groups: formal versus informal and, within those segments, mothers versus non-mothers. The first column is a decomposition of the formal-informal wage differential that seeks to prove the null hypothesis of equation (2), namely that earnings are significantly higher for formal than for informal workers. The mean predictor of the natural $\log$ of hourly wages is 1.05 pesos for informal workers and 1.48 pesos for formal workers, yielding a negative and significant difference of -0.43 . When the Blinder-Oaxaca decomposition is carried out, both parts are significant: $67 \%$ is explained by differences in personal, job or sectoral characteristics, while $33 \%$ is unexplained and could be considered evidence of labour market segmentation.

Since the aim is to understand not only the earnings differences between segments but also the posited motherhood wage penalty, the second and third columns of table 5 consider mothers versus non-mothers. As expected, given our central hypotheses, there are no

16 The results have to be interpreted with caution, however, because, as Esquivel (2009) emphasizes, attributing discrimination to the second component assumes that the first part, associated with supply-side factors, is free of discrimination. "[It] is particularly problematic if certain attributes of occupations are included as 'explained factors' in this first component, like industry, for example, because this implicitly assumes that segregation is due to the voluntary decisions of men and women" (Bergmann, 2004, quoted in Esquivel, 2009, p.18). significant differences between the predicted means of mothers and non-mothers in the formal sector. However, there is a motherhood wage penalty in the case of informal workers; the predicted natural log of the hourly wage is 1.15 pesos for non-mothers and 0.98 pesos for mothers. The positive wage gap of 0.16 in favour of nonmothers is significant, and almost the entire difference $(75 \%)$ is significantly unexplained or associated with possible discrimination. Thus, these findings bear out the original hypothesis of a motherhood wage penalty in the informal sector, and most of this penalty is attributable to discrimination or unobserved factors. ${ }^{17}$ It is also worth noting that this 0.16 differential in the informal sector is at the upper end of the distribution of the motherhood wage penalty estimates reported above.

\footnotetext{
17 In an attempt to identify the group of mothers experiencing the greatest motherhood penalty, we also estimated the Blinder-Oaxaca decomposition for different groups of formal and informal women: (a) mothers of one child versus all other women; (b) mothers of two children versus all other women and (c) mothers of three children versus all other women. In the formal sector, it seems evident that the main conclusion is as shown in table 6: mothers do not appear to experience wage penalties. In the informal sector, the largest motherhood penalty is found among mothers of three or more children, since the estimated predicted natural log of the hourly wage difference is significant and is equal to 0.32 . About $47 \%$ is explained by differences in endowments, while $53 \%$ of the decomposition is unexplained. As indicated previously, the Blinder-Oaxaca decomposition does not identify whether the unexplained part is discrimination by employers or unobserved heterogeneity in productivity.
}

Argentina (Greater Buenos Aires): Blinder-Oaxaca decomposition, formal and informal, 1995-2003

\begin{tabular}{|c|c|c|c|}
\hline \multirow[b]{2}{*}{ Group } & \multirow[b]{2}{*}{$\begin{array}{r}\text { Informal (1) } \\
\text { vs formal (2) }\end{array}$} & Formal & \multirow{2}{*}{$\begin{array}{c}\text { Informal } \\
\text { Non-mother (1) } \\
\text { vs mother (2) }\end{array}$} \\
\hline & & $\begin{array}{l}\text { Non-mother (1) } \\
\text { vs mother (2) }\end{array}$ & \\
\hline ln (rhourwage) Prediction_1 & $\begin{array}{l}1.05 \\
{[0.02] * * *}\end{array}$ & $\begin{array}{l}1.47 \\
{[0.02]^{* * *}}\end{array}$ & $\begin{array}{l}1.15 \\
{[0.03]^{* * *}}\end{array}$ \\
\hline In (rhourwage) Prediction_2 & $\begin{array}{l}1.48 \\
{[0.02] * * *}\end{array}$ & $\begin{array}{l}1.49 \\
{[0.02]^{* * *}}\end{array}$ & $\begin{array}{l}0.98 \\
{[0.02]^{* * *} *}\end{array}$ \\
\hline Difference & $\begin{array}{l}-0.43 \\
{[0.02]^{* * *}}\end{array}$ & $\begin{array}{c}-0.02 \\
0.03\end{array}$ & $\begin{array}{l}0.16 \\
{[0.04]^{* * *}}\end{array}$ \\
\hline \multicolumn{4}{|l|}{ Decomposition } \\
\hline Explained $^{\text {a }}$ & $\begin{array}{l}-0.29 \\
{[0.03] * * *}\end{array}$ & $\begin{array}{l}-0.03 \\
{[0.02]}\end{array}$ & $\begin{array}{c}0.04 \\
{[0.03]}\end{array}$ \\
\hline Unexplained ${ }^{\mathrm{b}}$ & $\begin{array}{l}-0.14 \\
{[0.03] * * *}\end{array}$ & $\begin{array}{c}0.01 \\
{[0.03]}\end{array}$ & $\begin{array}{l}0.12 \\
{[0.03]^{* * *}}\end{array}$ \\
\hline
\end{tabular}

Source: prepared by the authors on the basis of the Permanent Household Survey (EPH).

Note: the standard errors are listed below the estimates in brackets, and are robust to heteroskedasticity.

${ }^{a}$ Quality or endowments effect explained by group differences in the predictors.

${ }^{\mathrm{b}}$ Discrimination effect: unexplained effect attributed to discrimination and unobserved variables.

*** Significant at $1 \%$. 


\section{The Nopo decomposition}

The central variable is the natural log of real hourly wages, and we are analysing the wage gap between mothers and non-mothers working in the formal and informal sectors. Three combinations are taken in the matching: set I takes age and year, set II adds education measured by three dummy variables, and set III adds the head of household dummy variable. As Marquez Garcia, Nopo and Salardi (2009) highlight, the greater the number of characteristics used in the matching, the smaller the chances of finding exact matches. Notice in table 6 that the common support (Cs) percentage of mothers decreases from approximately $92 \%$ in set I to $50 \%$ in set III for the formal and informal subsamples, while the cs percentage of non-mothers decreases from $90 \%$ to $42 \%$ in the formal sector and from $95 \%$ to $57 \%$ in the informal sector.

When the formal subsample is considered, it transpires that non-mothers earn only $0.02 \%$ more than mothers. After matching on age and year, $1 \%$ is accounted for by differences in the support $\left(\Delta_{\mathrm{M}}=-0.1 \%\right.$ and $\left.\Delta_{\mathrm{NM}}=1.1 \%\right)$ and differences in the distribution of individual characteristics in the common support explain $3 \%\left(\Delta_{\mathrm{X}}\right)$, while $\Delta_{0}=-4 \%$ is the unexplained motherhood wage gap. Interestingly, when we add more characteristics (age, year, education and head of household), the unexplained gap is even smaller at $\Delta_{0}=$
$-1.2 \%$. Most is accounted for by the components that exist because of unmatchable mothers $\left(\Delta_{\mathrm{M}}=-4.6 \%\right)$ and non-mothers $\left(\Delta_{\mathrm{NM}}=3.6 \%\right)$.

When the informal sample is considered, the wage gap is found to be much greater here than in the formal sector: mothers earn $14.4 \%$ less than non-mothers. The largest share of the decomposition is accounted for by the unexplained component, and $\Delta_{0}$ accounts for $-15.8 \%$ in set I, $-13.6 \%$ in set II and $-17.5 \%$ in set III. As for the components associated with unmatched individuals, following inclusion of education and the head of household dummy the part of the gap for which there are mothers who cannot be matched with non-mothers $\Delta_{\mathrm{M}}$ yields a positive sign (1.5\% in set II and $6.1 \%$ in set III) while $\Delta_{\mathrm{NM}}$ yields a negative sign $(-3.3 \%$ in set II and $-6.7 \%$ in set III). Interestingly, the lowest share is given by a positive $\Delta_{\mathrm{X}}$ of $2.3 \%$ when only year and age are considered, $1.1 \%$ when education is added in and $3.7 \%$ when the head of household dummy is included.

Note that $\Delta_{\mathrm{X}}$ is always positive in both samples, and this could be understood as non-mothers having better endowments. Once again, these observations offer evidence in favour of our central hypotheses, since there are significant differences between the predicted means of mothers and non-mothers in the informal sector, and the unexplained wage gap component is significantly higher in the informal segment.

TABLE 6

Argentina (Greater Buenos Aires): motherhood wage gaps, formal and informal, 1995-2003

(Percentages)

\begin{tabular}{|c|c|c|c|}
\hline & \multicolumn{3}{|c|}{ Formal } \\
\hline & $\begin{array}{c}\text { (I) } \\
\text { Age and year }\end{array}$ & $\begin{array}{c}\text { (II) } \\
\text { Plus education }\end{array}$ & $\begin{array}{c}\text { (III) } \\
\text { Plus head of household }\end{array}$ \\
\hline$\Delta$ & -0.02 & -0.02 & -0.02 \\
\hline$\Delta_{0}$ & -4.01 & -3.83 & -1.1 \\
\hline$\Delta_{\mathrm{M}}$ & -0.10 & -4.00 & -4.60 \\
\hline$\Delta_{\mathrm{NM}}$ & 1.10 & 4.50 & 3.57 \\
\hline$\Delta_{\mathrm{X}}$ & 2.99 & 3.32 & 2.21 \\
\hline Percentage cs mothers & 91.97 & 67.62 & 49.48 \\
\hline \multirow[t]{3}{*}{ Percentage cs non-mothers } & 89.94 & 64.20 & 42.29 \\
\hline & \multicolumn{3}{|c|}{ Informal } \\
\hline & $\begin{array}{c}\text { (I) } \\
\text { Age and year }\end{array}$ & $\begin{array}{c}\text { (II) } \\
\text { Plus education }\end{array}$ & $\begin{array}{c}\text { (III) } \\
\text { Plus head of household }\end{array}$ \\
\hline$\Delta$ & -14.40 & -14.40 & -14.40 \\
\hline$\Delta_{0}$ & -15.78 & -13.59 & -17.48 \\
\hline$\Delta_{\mathrm{M}}$ & -1.06 & 1.46 & 6.11 \\
\hline$\Delta_{\mathrm{NM}}$ & 0.13 & -3.34 & -6.74 \\
\hline$\Delta_{\mathrm{X}}$ & 2.32 & 1.08 & 3.72 \\
\hline Percentage cs mothers & 91.81 & 64.90 & 46.85 \\
\hline Percentage cs non-mothers & 95.45 & 76.20 & 57.06 \\
\hline
\end{tabular}

Source: prepared by the authors on the basis of the Permanent Household Survey (EPH).

Note: wages gaps were estimated using the Nopo decomposition, controlling for different sets of characteristics. 


\section{VI}

\section{Conclusions}

This article is unique in that it integrates two different topics, the motherhood wage penalty and segmented labour markets in the recent Argentine context of national policies pursuing flexible labour markets and the consequent deterioration of workers' rights. In general, we cannot reject the traditional hypothesis of labour market segmentation and a wage premium for formal-sector women workers. Our central finding is that women working in the informal sector are the ones who suffer a motherhood wage penalty. It appears that regulations protecting the rights of these mothers go unenforced and they are less able to afford domestic help and childcare that might enable them to become more productive at work. Women who have more children show a greater likelihood of being in a temporary job, perhaps because they have to allocate more time to taking care of the family in the home. It is also true that not all women have the same employment opportunities, and those who belong to the lowest income segments have to work under more insecure and informal conditions because of their need to contribute to household income.

We use different estimation methods, including analysis of frequency distributions, oLs and quantile regressions. We combine the oLs results with the BlinderOaxaca decomposition to explore the explained and unexplained sources of wage gaps. The regression analysis shows that not all women experience the motherhood wage penalty. In the case of formal-sector workers, the coefficients on the motherhood dummy are not significant; it appears clear that those mothers do not experience wage penalties. In the case of the informal subsample, wage penalties are significant and grow with the number of children. Moreover, the motherhood penalty is not the same across the conditional wage distribution since it tends, especially for informal women, to be greater at the extremes. These results are consistent with the glass ceiling and sticky floor hypotheses of the labour market literature.

Additionally, considering the Blinder-Oaxaca decomposition, the difference between formal and informal wages is significant, and while $67 \%$ of the difference is explained, $33 \%$ is unexplained and could be attributed to discrimination. When motherhood and its effects on women's wages are considered, there are significant results in the informal subsample, mainly for the estimated coefficient of motherhood, while there are no significant estimates in the formal group. In the case of the informal segment, there is strong evidence of a motherhood wage penalty, and it is almost entirely (75\%) driven by unexplained factors or discrimination. Similar results arise with the Nopo decomposition; most of the motherhood wage penalty in the informal sector is unexplained, and when we add more characteristics to the match it is greater than the actual gap $(\Delta=-14.4 \%$ and $\Delta_{0}=-17.5 \%$ ).

Overall, this article shows that the most vulnerable women are informal-sector workers. Their vulnerability is observed not only in their wages, which are lower than formal-sector women's, but also in a motherhood wage penalty that rises with the number of children and is greatest when children are young. Institutional labour market rules thus appear to be a crucial determinant of wages for women in Buenos Aires. These results suggest a welfare rationale for caution in pushing for increased labour market flexibility. Such reforms might drive standards down towards those applied to mothers in the informal sector, reducing pay and professional opportunities. 
ANNEX

TABLE A.1

Explanation of variables

\begin{tabular}{|c|c|}
\hline Variable & Description \\
\hline rhourwage & Real hourly wage. \\
\hline ln_rhourwage & Natural log of the real hourly wage. \\
\hline dformal & Dummy: 1 if the woman is employed in the formal sector and 0 otherwise. \\
\hline dmother & Dummy: 1 if the woman is the mother of at least one child aged under 15 and 0 otherwise. \\
\hline dmother_one & Dummy: 1 if the mother has one child aged under 15 living at home and 0 otherwise. \\
\hline dmother_two & Dummy: 1 if the mother has two children aged under 15 living at home and 0 otherwise. \\
\hline dmother_more & Dummy: 1 if the mother has more than two children aged under 15 living at home and 0 otherwise. \\
\hline dmother_5 & Dummy: 1 if the mother has at least one child aged under 6. \\
\hline dmother_6-14 & Dummy: 1 if the mother has at least one child aged 6 to 14 . \\
\hline age & The woman's age in years. \\
\hline agesq & The square of the woman's age in years. \\
\hline dsingle & Dummy: 1 if the woman is single and 0 otherwise. \\
\hline dmarried & Dummy: 1 if the woman is married and 0 otherwise. \\
\hline ddivorced & Dummy: 1 if the woman is divorced and 0 otherwise. \\
\hline education 1 & Dummy: 1 if the woman has incomplete secondary education or less and 0 otherwise. \\
\hline education2 & Dummy: 1 if the woman has complete secondary education or some university-level education and 0 otherwise. \\
\hline education3 & Dummy: 1 if the woman has completed a university degree and 0 otherwise. \\
\hline yearsinjob & Number of years working in the current job. \\
\hline dfulltime & Dummy: 1 if the woman works more than 20 hours per week and 0 otherwise. \\
\hline dparttime & Dummy: 1 if the woman works less than 20 hours per week and 0 otherwise. \\
\hline dpublic & Dummy: 1 if the woman is employed in the public sector and 0 otherwise. \\
\hline dprivate & Dummy: 1 if the woman is employed in the private sector and 0 otherwise. \\
\hline dfirm_small & Dummy: 1 if the woman is employed in a firm with one employee and 0 otherwise. \\
\hline dfirm_medium & Dummy: 1 if the woman is employed in a firm with two to five employees and 0 otherwise. \\
\hline dfirm_large & Dummy: 1 if the woman is employed in a firm with more than five employees and 0 otherwise. \\
\hline dmanufacturing & Dummy: 1 if the worker is employed in the manufacturing sector and 0 otherwise. \\
\hline dcommerce & Dummy: 1 if the worker is employed in the commerce sector and 0 otherwise. \\
\hline dservice & Dummy: 1 if the worker is employed in the service sector and 0 otherwise. \\
\hline manager & Dummy: 1 if the woman is a manager and 0 otherwise. \\
\hline service & Dummy: 1 if the woman is a services worker and 0 otherwise. \\
\hline bluecollar & Dummy: 1 if the woman is a blue-collar worker and 0 otherwise. \\
\hline
\end{tabular}

Source: prepared by the authors.

\section{Bibliography}

Amuedo-Dorantes, C. and J. Kimmel (2005), "The motherhood wage gap for women in the United States: the importance of college and fertility delay", Review of Economics of the Household, vol. 3, No. 1, Springer.

Anderson, D., M. Binder and K. Krause (2003), "The motherhood wage penalty revisited: experience, heterogeneity, work effort and work-schedule flexibility", ILR Review, vol. 56, No. 2, Cornell, Cornell University.

(2002), "The motherhood wage penalty: which mothers pay it and why?", American Economic Review, vol. 92, No. 2, Nashville, Tennessee, American Economic Association.

Babcock, L. and S. Laschever (2003), Women Don't Ask: Negotiation and the Gender Divide, Princeton, Princeton University Press.

Bauder, H. (2001), "Culture in the labor market: segmentation theory and perspectives of place", Progress in Human Geography, vol. 25, No. 1, Sage.

Beblo, M., S. Bender and E. Wolf (2009), "Establishment-level wage effects of entering motherhood", Oxford Economic Papers, vol. 61(S1), Oxford University Press.
Bergmann, B. (2004), "Two varieties of 'feminist"”, Newsletter, vol. 14, No. 4, Lincoln, Nebraska, International Association for Feminist Economics.

Blinder, A. (1973), "Wage discrimination: reduced form and structural estimates", Journal of Human Resources, vol. 8, No. 4, Wisconsin, University of Wisconsin Press.

Botelho, F. and V. Ponczek (2011), "Segmentation in the Brazilian labor market", Economic Development and Cultural Change, vol. 59, No. 2, Chicago, The University of Chicago Press.

Buchinsky, M. (1998), "Recent advances in the quantile regression models: a practical guideline for empirical research", The Journal of Human Resources, vol. 33, No. 1, Wisconsin, University of Wisconsin Press.

Budig, M. and P. England (2001), "The wage penalty for motherhood", American Sociological Review, vol. 66, No. 2, Washington, D.C., American Sociological Association.

Casal, M. (2011), Motherhood Wage Penalty and Labor Market Segmentation in Argentina, Madison, University of Wisconsin-Madison. 
Correll, S., S. Benard and I. Paik (2007), "Getting a job: is there a motherhood penalty?", American Journal of Sociology, vol. 112, No. 5, Chicago, The University of Chicago Press.

De Pablo, J. (2005), La economía argentina: En la segunda mitad del siglo XX, Buenos Aires, La Ley.

Esquivel, V. (2009), "Care workers in Argentina", Argentina Research Report, No. 4, Geneva, United Nations Research Institute for Social Development (UNRISD), draft.

Falaris, E. (2008), "A quantile regression analysis of wages in Panama", Review of Development Economics, vol. 12, No. 3, Wiley Blackwell.

Faur, E. (2011), "A widening gap? The political and social organization of childcare in Argentina", Development and Change, vol. 42 , No. 4.

(2008a), "Historical context: economic, demographic and social structures and trajectories, and social policies in Argentina", Argentina Research Report, No. 1, Geneva, United Nations Research Institute for Social Development (UNRISD), draft. (2008b), "The care diamond: social policy regime, care policies and programmes in Argentina", Argentina Research Report, No. 3, Geneva, United Nations Research Institute for Social Development (UNRISD), draft.

Fields, G. (2008), "Segmented labor market models in developing countries", ILR School Collection, No. 162, Cornell, Cornell University.

Gangl, M. and A. Ziefle (2009), "Motherhood, labor force behavior, and women's careers: an empirical assessment of the wage penalty for motherhood in Britain, Germany, and the United States", Demography, vol. 46, No. 2.

Gong, X. and A. van Soest (2002), "Wage differentials and mobility in the urban labour market: a panel data analysis for Mexico", Labour Economics, vol. 9, No. 4, Amsterdam, Elsevier.

Goldin, C. (2006), "The quiet revolution that transformed women's employment, education, and family", American Economic Review, vol. 96, No. 2, Nashville, Tennessee, American Economic Association.

Heckman, J. (1979), "Sample selection bias as a specification error", Econometrica, vol. 47, No. 1, New York, The Econometric Society.

INDEC (National Institute of Statistics and Censuses) [online] http://www.indec.mecon.ar.

Jann, B. (2008), "A Stata implementation of the Blinder-Oaxaca decomposition", ETH Zurich Sociology Working Papers, No. 5, Zurich, Swiss Federal Institute of Technology.

Kennelly, I. (1999), "That single-mother element: how white employers typify black women", Gender and Society, vol. 13, No. 2, Sage Publications.

Koenker, R. and K. Hallock (2001), "Quantile regression”, Journal of Economic Perspectives, vol. 15, No. 4, Nashville, Tennessee, American Economic Association.

Maloney, W. (1999), "Does informality imply segmentation in urban labor markets? Evidence from sectoral transitions in Mexico", World Bank Economic Review, No. 13, Washington, D.C., World Bank.

Marquez Garcia, L., H. Ñopo and P. Salardi (2009), "Gender and racial wage gaps in Brazil 1996-2006: evidence using a matching comparisons approach", Working Paper, No. 4626, Washington, D.C., Research Department, Inter-American Development Bank. Mincer, J. (1974), Schooling, Experience, and Earnings, New York, Columbia University Press.

Ñopo, H. (2008), "Matching as a tool to decompose wage gaps", Review of Economics and Statistics, vol. 90, No. 2, Cambridge, Massachusetts, The MIT Press.

Oaxaca, R. (1973), "Male-female wage differentials in urban labor markets", International Economic Review, vol. 14, No. 3, Philadelphia, University of Pennsylvania/University Institute of Social and Economic Research Association.

Olbrecht, A. (2009), "Do academically deficient scholarship athletes earn higher wages subsequent to graduation?", Economics of Education Review, vol. 28, No. 5, Amsterdam, Elsevier.

Packard, T. (2007), "Do workers in Chile choose informal employment? A dynamic analysis of sector choice", Policy Research Working Paper, No. 4232, Washington, D.C., World Bank.

Pagés, C. and M. Stampini (2007), "No education, no good jobs? Evidence on the relationship between education and labor market segmentation", IZA Discussion Paper, No. 3187, Bonn, IZA Institute for the Study of Labor.

Pastor, M. and C. Wise (1999), "Stabilization and its discontents: Argentina's economic restructuring in the 1990s", World Development, vol. 27, No. 3, Amsterdam, Elsevier.

Piras, C. and L. Ripani (2005), "The effects of motherhood on wages and labor force participation: evidence from Bolivia, Brazil, Ecuador and Peru", Sustainable Development Department Technical Papers Series, No. 109, Washington, D.C., Inter-American Development Bank.

Pratap, S. and E. Quintin (2006), "Are labor markets segmented in developing countries? A semiparametric approach", European Economic Review, vol. 50, No. 7, Amsterdam, Elsevier.

Ridgeway, C. and S. Correll (2004), "Unpacking the gender system: a theoretical perspective on gender beliefs and social relations", Gender \& Society, vol. 18, No. 4, Sage Publications.

Rosenzweig, M.R. (1988), "Labor markets in low-income countries", Handbook of Development Economics, Hollis Chenery and T.N. Srinivasan (eds.), vol. 1, New York, North-Holland.

Torrado, S. (2003), Historia de la familia en la Argentina moderna (1870-2000), Buenos Aires, Ediciones de la Flor.

Waldfogel, J. (1998), "Understanding the 'family gap' in pay for women with children", The Journal of Economic Perspectives, vol. 12, No. 1, Nashville, Tennessee, American Economic Association. (1997), "The effect of children on women's wages", American Sociological Review, vol. 62, No. 2, Washington, D.C., American Sociological Association.

(1995), "The price of motherhood: family status and women's pay in young British cohort", Oxford Economic Papers, vol. 47, No. 4, Oxford, Oxford University Press.

Wooldridge, J. (2000), Introductory Econometrics: A Modern Approach, South Western College.

Yasmin, B. (2009), "Trade liberalization and the lead role of human capital and job attributes in wage determination: the case of Pakistan's labor market", The Lahore Journal of Economics, vol. 14, No. 1, Lahore, The Lahore School of Economics. 